\title{
Material Requirements Planning Methods to Solve Inventory Problem at Start-Up Business
}

\author{
Widianingsih \\ Program Studi Kewirausahaan \\ Institut Teknologi Bandung \\ Bandung, Indonesia \\ Widianingsih@sbm-itb.ac.id
}

\author{
Desy Anisya Farmaciawaty \\ Sekolah Bisnis dan Manajemen \\ Institut Teknologi Bandung \\ Bandung, Indonesia
}

\begin{abstract}
Currently in Indonesia, start-up business is growing fastly due to goverment policy that promote the rise of the new entrepreneurs. KISSE (Cookies Sehat) is among many start-up business in Indonesia, which is in Bandung, that focus in culinary particularly in healthy cookies. As a start-up business, they are still facing some problems and challenges to grow their business, such as inventory system and production scheduling problem. Therefore, we conduct the reseach to develop the solution to the inventory problems faced by KISSE Company. The objective of this research is to implement material requirement planning (MRP) in KISSE Company in order to solved their inventory problems and production scheduling. Material requirement planning is a methods that are used to control inventory and production planning especially to schedule and decide how much raw material is needed in producing goods. To do this research, we collect primary data by observing the production division at KISSE Company. From those data, then we forecast independent demand, create the bill of material, and develop the master production scheduling. The result of this research is the formulation of MRP system for startup business that would make their inventory system and production scheduling more effective and efficient.
\end{abstract}

Keywords-Material Requirements Planning (MRP); Start-up business; inventory problem; production scheduling.

\section{INTRODUCTION}

According to data from www.bps.go.id regarding the number of companies in the micro and small enterprises in Indonesia from 2014-2015, there is an increase in the number of micro enterprises in Indonesia from 3,220,563 companies into $3,385,851$ companies. Particularly in the culinary sector, especially food and beverages, there is an increase in the number of micro and small enterprises (2014-2015), from $1,125,425$ companies into $1,473,205$ companies for microenterprises and from 73.066 into 93.814 companies for small enterprises [1]. Based on these data, it can be seen that MSMEs in Indonesia have a fairly rapid growth. In addition, the growth of MSMEs have also had a positive meaning to economic growth in Indonesia.
Micro-businesses in the food and beverage industry become highly essential to discuss because of its growth that had reached of more than 300,000 business units in a year. It means that there are more than 300,000 new business unit are developed in Indonesia. The startup business will be the hope of Indonesia to increase the welfare of the people and also reduce unemployment. For that, in its development, these micro businesses should be assisted, not only in terms of capital but also management so that there will be no competency gap in business.

In addition to marketing and sales distribution, one that is no less important in supporting a business is operation/production. Operation/production has an important role for the creation of a quality product in an effort to meet consumer demand. However, startup business in the food and beverage industry has constraints in managing the operation. This is because the startup business has still little experience in running a business, especially in managing inventory and production schedules as demand is not yet stable.

The availability of stock in inventory has a positive or negative impact in business. In terms of positives, the availability of stocks will make a company to be able to meet consumer demand directly or avoid stock out. It also will indirectly affect consumer loyalty to the products of the companies. While the negative one is that the holding costs will burden the company. Therefore, a good ability to manage and to schedule inventory is needed in order to produce a decent production activity to meet customer demand. One method that is often used to overcome this problem is the material requirements planning (MRP), which is a method commonly used to translate the master production schedule of end product in analyzing raw materials needed and determine when the raw materials must be available [2].

One of start-up business in Bandung which focus on the culinary field is KISSE (Cookies Sehat) that producing healthy cookies. A great goal of KISSE (Cookies Sehat) is to become an alternative product for people who care about their health and weight. To achieve the great goal, the management team specify strategy such as the raw material used in the production must comply high quality. In addition, they also want to achieve high profits not only by increasing sales significantly but also by having wide distribution channels throughout Indonesian market. 
KISSE (Cookies Sehat) currently works in a limited facilities. In one month, KISSE (Cookies Sehat) perform all production process once in two weeks and make the production in the weekend, thus they produce twice in a month. In one time, KISSE (Cookies Sehat) can produce about 60-100 packs of cookies. Therefore, KISSE (Cookies Sehat) can produce about maximum 200 pcs per month. In addition, they need about 9 hours to do the production process with the result of production still can not meet the potential demand.

Based on fishbone analysis, there are four classifications problem, which are methods, materials, machinery, and man, used to classify the causes of the problem faced by KISSE. The problem in the methods are: no SOP (standard operating procedure) from making cookies, there is no production scheduling, business processes are not clear enough. Then, the problems that exist in the material is: under-stock of raw materials, raw materials that are easily damaged, there is no inventory records. The problem in the machine is: the oven used were simple oven or manual oven. The existing problems in human power are: the lack of employees for production.

From the above problems, the most significant issues is the system of inventory and production scheduling. These problems adversely affect the performance of the company to meet demand of the product. One method that can be used to solve these problems is the material requirements planning (MRP), which is a formulation used to adjust inventory and production schedules.

\section{LITERATURE REVIEW}

\section{A. Start Up Business}

Start up business is a business activity that started with an aim to solve technical problems in the communities and can be associated with finding new things that can be utilized by the community [3]. Start up a business is often associated with technology, but basically a start-up business is a new venture that is run by the stages of start designing ideas, concepts, management, products and also strategy.

Start-up businesses must pass three phases, the phase of pre-start-up, start-up and growth [4]. It is because, each startup has a different time depending on the achievement of what the work done. In the pre-start-up phase, ideation and concepting is the key in establishing start-up businesses. The founders will be confronted with the purpose of creating the business, to whom the business is aimed and also what distinguishes those businesses with other businesses. Once it is created, the founders of start-ups will be faced with a commitment, which is the beginning of the start-up phase. In this commitment, the founders will start executing its business. In the start-up phase there is validation, validation is the stage where the products begin to enter the market, and do the market test to find out market response to products launched. After that, business start-ups will experience scaling, which is the stage where the product has to have a clear target market and have been accepted by the market. At this stage, there are start-up businesses that grow in quick time, and those that grow in a slow time. Next business startup will enter the phase of growth. This phase is the culmination point, the business will became establish and achieve growth and great success.

\section{B. Forecasting Demand}

One way that is done in demand management is to conduct forecasting demand. Forecasting demand is a method to measure the amount of which will be produced to be sold to the market [5]. This is done to avoid a mismatch between demand and supply. Qualitative, time series analysis, causal relationship and simulation are four basic types of forecasting [6]. Qualitative forecasting is a technique that is done by combining the experience and judgment or assessment of personal [7]. Time series analysis is a forecasting technique that is done by using past data for predicting demand in the future, and past data in question consist of trend, seasonal, and cyclical [6]. Causal relationship is a forecasting technique that is performed by using a linear regression technique, which considers that the demand can be affected by several factors in the environment [6]. Meanwhile, simulations are forecasting technique that is done by running some kind of supposition about the conditions of which will be in the forecast [6].

\section{Inventory}

Inventory is the stock of goods related to business, but every type of business has different types of inventory. For example, the inventory required by manufacturing companies will be different from the inventory required by supermarkets. The core of the inventory function is that there is no big gap between customer demand with available stock, in addition to avoiding stocks are not available because things are unpredictable as the weather and human error [8].

Inventory management or commonly referred to as inventory control has a purpose, which are customer satisfaction towards the availability of goods at the time of purchase and also minimize excessive inventory costs due to unstructured inventory [8].

Inventory counting system is a system that is used in the calculation of inventory within a company. There are two types of inventory counting system, which are the periodic system and the perpetual system. Periodic inventory system is a system that is counted in the calculation of any given period, be it weekly or monthly period. Meanwhile, the inventory perpetual inventory calculations are carried out continuously to maintain the change of trail inventory in each of the activities [8].

\section{Scheduling}

Scheduling is an application used to decide the production planning activities undertaken from day to day and from time to time [5]. By using the scheduling method, then the existing production activities in the company will be more composed and structured. So this will affect the level of effectiveness and efficiency in the company. There are three types of scheduling, the scheduling for repetitive system, scheduling for batch system, and scheduling for jobbing system.

Scheduling for repetitive system is a system used to prioritize workflow from one production line. The system is 
applicable for standard products and large quantities or mass production, it is because this system produces repetitive and mostly used for the kind of orders that make to stock [5]. The scheduling for batch system is a system used to prioritize work in a group. The system is applied to a product that has a combination of products that have a variety of products and must be produced in considerable amounts, so the system is used for the kind of orders that assembly to order [5]. While scheduling for jobbing system is a system that used to adjust to some job in the production process. The system is applied to a product that has a number of production but with a slightly different variations in each product, so that the system is used for the kind of orders that make to order [8].

\section{E. Material Requirements Planning}

Material requirements planning system is created as an alternative inventory control in answering any materials needed, how much its needed, and when the material will be used. So, it will result in the formulation of reservations and schedules for each activity production [8]. There are several advantages of using MRP, such as the company will have a faster response to the market, a better system of inventory planning and scheduling, and also have efficient stock without having to disappoint customers because the product is not available [2].

There are three important parts of MRP which are MRP inputs, MRP processing, and MRP outputs.

Parts included in MRP inputs are master production scheduling (MPS), the bill of materials (BOM), and also inventory records. Master production scheduling is a calculation capacity of the company to the customer demands in terms of time, such as quantity and time buckets. Bill of material is the quantity and structure of the material component to become a single product [8]. Meanwhile, inventory records record the availability and the settings of each material required in production.

Master production scheduling analyze the quantity of product to be produced in accordance with the number of how many inventory and when the inventory needed [5]. The quantity in question is the customer orders, forecasts, and also the order of the warehouse for seasonal inventory and external demand. Bill of material is a hierarchical form of assemblies, sub-assemblies of parts, and raw materials. Furthermore, inventory records or invetory status file are records that detail the existing items, such as suppliers, lead time, and lot size. The accuracy of this listing is important because if not, then the quantity and delivery time will not be in accordance with existing expectations.

Parts included in the MRP Processing called MRP calculating or MRP computer programs. MRP computer programs is a formula of calculation in analyzing the results with this method [8]. There are some parts of the MRP processing, ie gross requirement, scheduled receipts, projected on hand, and net requirements.

While included in the MRP outputs are reports of primary and secondary records. Reports are part of the primary changes, order release, and planned-order schedules. And for the records is part of a secondary control performance reports, planning reports, and exception reports [8].

\section{METHODOLOGY}

\section{A. Collecting Data}

In collecting the data, the methods used is the observational methods to start-up businesses, in this study we aimed KISSE Company. Observation is a method of data collection which is done by a systematic observation of the object under study, then we record everything found throughout the process [9]. There are several forms of observation, including participant observation and nonparticipant observation.

Participant observation is a form of observation by participating or taking part in activities conducted by the target object [9]. While the non-participant observation is a form of observations made by observing the behavior of a target object without directly involved [10]. In this study, we use the observation participant method in KISSE Company, with this observation, researchers will be directly involved in the activities at the company's operation. In addition, this study requires data from the internal KISSE Company, such as sales data and bill of materials.

Observation guidelines have a purpose as a reference during the data collection process. These guidelines include indicators that have to be done and the information that must be obtained in doing participant observation. The scope of the observation participant method is limited in the operation division that directly related to the production process of the cookies. As for the indicators to be done and the information that must be obtained in these observations is as follows.

○ Business processes in the operation of the activities from preparation to packaging. This is achieved by means of participating in the activities of production companies.

o Root-cause analysis of KISSE Company. This is achieved by observing the existing gap in the business processes of the company and also through production activities that have been carried out.

\section{B. Analyzing Data}

After data collection is done, the next is processing the data that has been obtained and perform data analysis. Before the data were analyzed, the data will be filtered to suit the purpose of this study and to avoid unnecessary data. In this study, the method used material requirements planning (MRP) in solving inventory and scheduling problems. MRP method has several steps that must be done before getting the proper formulation to solve the problem. The stages that must be done is independent demand forecast, bill of materials, and master production scheduling.

Forcasting performed in this study using historical data of sales of company start-ups, then do analysis with Minitab software, and apply some methods such as time series and moving average. The forecasting results are compared with 


\section{$\triangle$ ATLANTIS PRESS}

each other, then the selected method of quadratic trend models, which is a method that has the smallest error.

Table 1. Forcasting Analysis

\begin{tabular}{|l|r|r|c|}
\hline & MAPE & MAD & MSD \\
\hline Double Exponential Method & 24,642 & 20,81 & 586,045 \\
\hline Single Exponential Method & 30,04 & 26,48 & 1193,06 \\
\hline Moving Average Length 2 & 19,689 & 25,625 & 897,313 \\
\hline Moving Average Length 3 & 22,72 & 31,22 & 1192,04 \\
\hline Trend Analysis Growth Curve Model & 11,085 & 9,784 & 140,023 \\
\hline Trend Analysis Quadratic Trend Model & 10,544 & 10,305 & 119,605 \\
\hline Trend Analysis S-Curve Trend Model & 10,34 & 11,222 & 156,187 \\
\hline Trend Analysis Linear Trend Model & 10,679 & 10,305 & 119,803 \\
\hline Winters Method & 10,04 & 11,135 & 223,402 \\
\hline
\end{tabular}

Meanwhile, Bill of material is a raw material that is used by a product. In this study, the raw materials are applied to the bill of material, the raw material per batch. Which is included in the bill of materials is the product structure and quantity of material required. With the bill of material, it will be able to count the number of raw materials needed in every production.

After independent demand forecast and the bill of materials, then made master production scheduling is a production schedule that will be done in a period. Which include master production scheduling is a time phase product structure or time buckets, master production scheduling can be formulated in the form of Microsoft Excel.

\section{DATA ANALYSIS}

\section{A. Description of Data Statistics}

\section{Forecast The Independent Demand}

Forecasting analysis is performed using quadratic trend models. This analysis uses actual sales of KISSE (Cookies Sehat) for six months i.e. from November 2015 to April 2016. The actual sales from November 2015 to April 2016 is shown below.

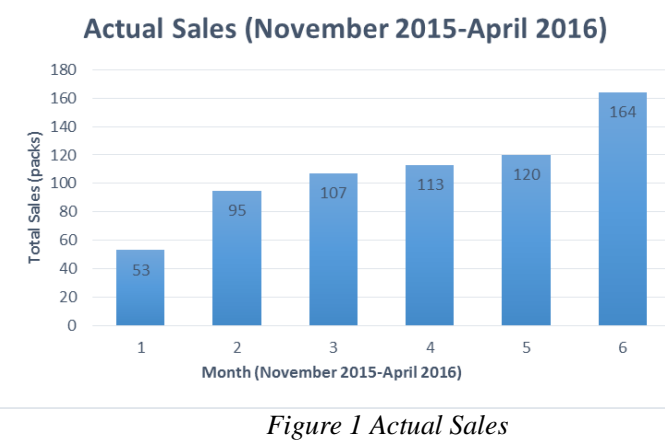

From the results it can be seen that the total sales achieved by the company continues to increase. With total sales in the month of November 2015 is 53 packs, in December 2015 is 95 packs, in January 2016 is 107 packs, in February 2016 is 113 packs, in March 2016 is 120 packs, and in April 2016 is 164 packs. Then, we forecasted the independent demand for next 12 months, and the results by using quadratic trend analysis is shown as follows.

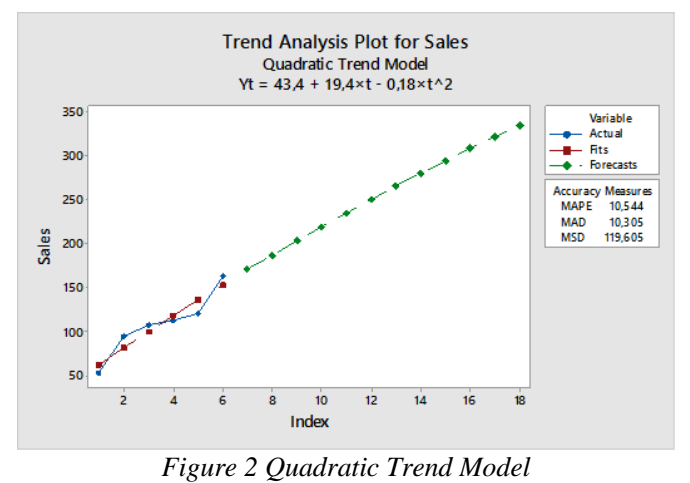

From the results of the forecast, it can be seen that the trend of demand is likely to increase. The results of this forecasting sequentially from seventh period to eighteenth period are 171, 187, 204, 220, 235, 251, 266, 280, 295, 308, 322, and 335 packs. The forecast results became aggregate planning of KISSE company during the next year.

As already known, cookies product is one product that has the possibility of seasonal sales such as Eid and Christmas. However, we did not use the seasonal sales technique because the actual data that is owned so far by the company are only 6 months. Moreover, these cookies product has economical packaging for one meal, so it can be consumed as a daily snack.

\section{Product Structure}

The next is to form hierarchical structure to prepare material required in making the product. The product structure of KISSE (Cookies Sehat) are as follows.

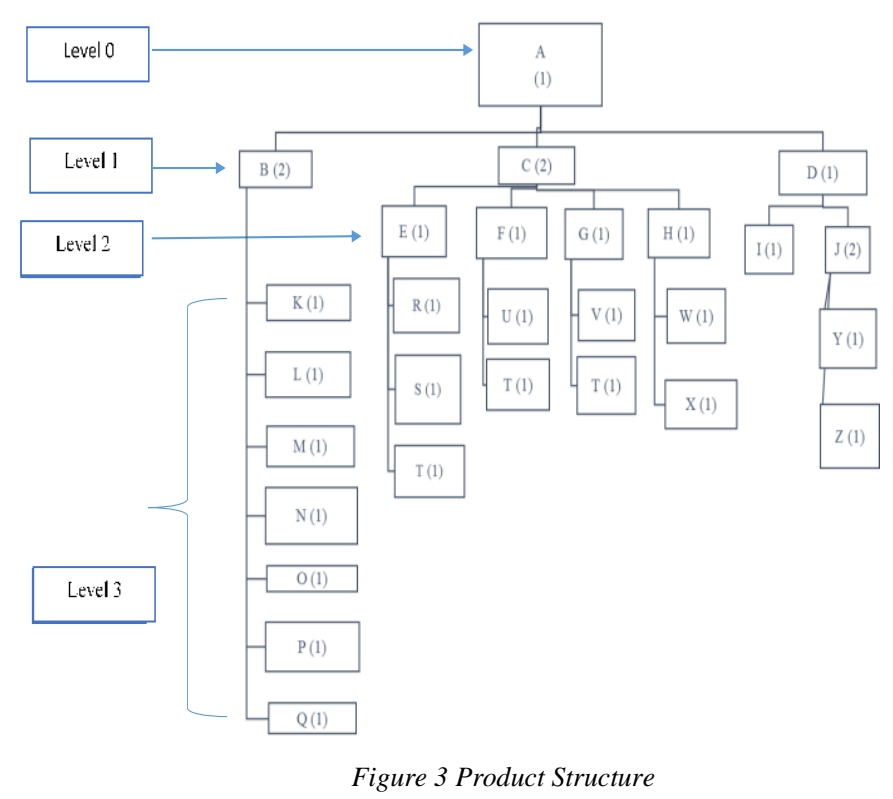


Table 2 The Description of Product Structure

\begin{tabular}{|c|c|}
\hline $\mathrm{A}=$ Cookies per batch & $\mathrm{N}=$ Dediccated coconut $25 \mathrm{gr}$ \\
\hline $\mathrm{B}=$ Dough & $\mathrm{O}=$ Salt $0,5 \mathrm{gr}$ \\
\hline $\mathrm{C}=$ Filling & $\mathrm{P}=$ Baking powder $0,5 \mathrm{gr}$ \\
\hline $\mathrm{D}=$ Packaging & $\mathrm{Q}=$ Vanili $0,5 \mathrm{gr}$ \\
\hline $\mathrm{E}=$ Chocolate Flavor & $\mathrm{R}=$ Compound choco $5 \mathrm{gr}$ \\
\hline $\mathrm{F}=$ Greentea Flavor & $\mathrm{S}=$ Choco powder $4 \mathrm{gr}$ \\
\hline $\mathrm{G}=$ Coffee Flavor & $\mathrm{T}=$ Almond 1gr \\
\hline $\mathrm{H}=$ Apple Flavor & $\mathrm{U}=$ Greentea 4gr \\
\hline $\mathrm{I}=$ Plastic & $\mathrm{V}=$ Coffee $4 \mathrm{gr}$ \\
\hline $\mathrm{J}=$ Sticker & $\mathrm{W}=$ Apple $100 \mathrm{gr}$ \\
\hline $\mathrm{K}=$ Oatmeal $500 \mathrm{gr}$ & $\mathrm{X}=$ Cinnamons $0,25 \mathrm{gr}$ \\
\hline $\mathrm{L}=$ Coconut oil $150 \mathrm{ml}$ & $\mathrm{Y}=1$ st Sticker \\
\hline $\mathrm{M}=$ Palm sugar 160gr & $\mathrm{Z}=2$ nd Sticker \\
\hline
\end{tabular}

In the product structure, it can be seen that in production process, the company has a component level from level 0 to level 3 . At level 0 , there are cookies that have been finished and packing. At level 1, there is the main component such as dough, filling, and packaging. At level 2, there is a component of the filling and packaging. Meanwhile, at level 3 are the basic components of these cookies.

\section{Bill of Material}

After creating the product structure, the next step is preparing the bill of materials based on the quantity to be produced and the raw material needed. The bill of materials in question are as follows.

Table 3 Bill of Material

\begin{tabular}{|c|c|c|c|}
\hline $\begin{array}{c}\text { Component } \\
\text { Code }\end{array}$ & $\begin{array}{c}\text { Component } \\
\text { Level }\end{array}$ & Item & $\begin{array}{l}\text { Number of } \\
\text { Item }\end{array}$ \\
\hline A & 0 & Cookies per batch & 1 \\
\hline $\mathrm{B}$ & \multirow{3}{*}{1} & Dough & 2 \\
\hline $\mathrm{C}$ & & Filling & 2 \\
\hline $\mathrm{D}$ & & Packaging & 1 \\
\hline $\mathrm{E}$ & \multirow{6}{*}{2} & Chocolate Flavor & 1 \\
\hline $\mathrm{F}$ & & Green tea Flavor & 1 \\
\hline $\mathrm{G}$ & & Coffee Flavor & 1 \\
\hline $\mathrm{H}$ & & Apple Flavor & 1 \\
\hline I & & Plastic & 1 \\
\hline $\mathrm{J}$ & & Sticker & 2 \\
\hline $\mathrm{K}$ & \multirow{16}{*}{3} & Oatmeal 500gr & 1 \\
\hline $\mathrm{L}$ & & Coconut oil $150 \mathrm{ml}$ & 1 \\
\hline M & & Palm sugar 160gr & 1 \\
\hline $\mathrm{N}$ & & Dedicated coconut $25 \mathrm{gr}$ & 1 \\
\hline $\mathrm{O}$ & & Salt $0,5 \mathrm{gr}$ & 1 \\
\hline $\mathrm{P}$ & & Baking powder $0,5 \mathrm{gr}$ & 1 \\
\hline $\mathrm{Q}$ & & Vanilli $0,5 \mathrm{gr}$ & 1 \\
\hline $\mathrm{R}$ & & Compound Choco 20gr & 1 \\
\hline $\mathrm{S}$ & & Choco powder $15 \mathrm{gr}$ & 1 \\
\hline $\mathrm{T}$ & & Almond 3gr & 3 \\
\hline $\mathrm{U}$ & & Green tea $15 \mathrm{gr}$ & 1 \\
\hline $\mathrm{V}$ & & Coffee 17gr & 1 \\
\hline $\mathrm{W}$ & & Apple 400gr & 1 \\
\hline $\mathrm{X}$ & & Cinnamons $0,5 \mathrm{gr}$ & 1 \\
\hline $\mathrm{Y}$ & & 1st sticker & 1 \\
\hline $\mathrm{Z}$ & & 2nd sticker & 1 \\
\hline
\end{tabular}

Time Phase Product Structure

Then, to determine the lead time of each process, we made time phase product structure. By the time phase product structure, we can see how long it takes to produce the product. The time phase product structure is as follows.

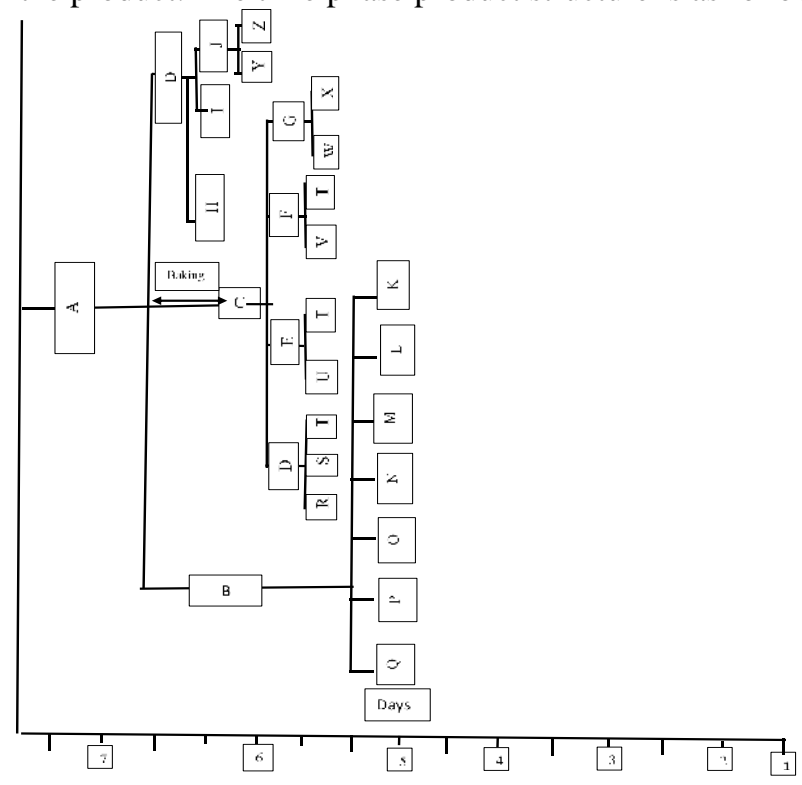

Figure 4 Time Phase Product Structure

We made a production timeline that have full schedule of activities at the end of the week. This is because KISSE company has a production time at weekend. Therefore, what is needed is to utilize the limited production time effectively and efficiently, as well as having a better raw material inventory system.

\section{B. Description of Data Statistics}

\section{Master Production Schedule}

After forecasting the independent demand, then we prepare a master production structure (MPS). In doing this, we adapt the production, from per pack in to per batch. The master production structure (MPS) that has been adjusted as follows.

Table 4 Master Production Scheduling

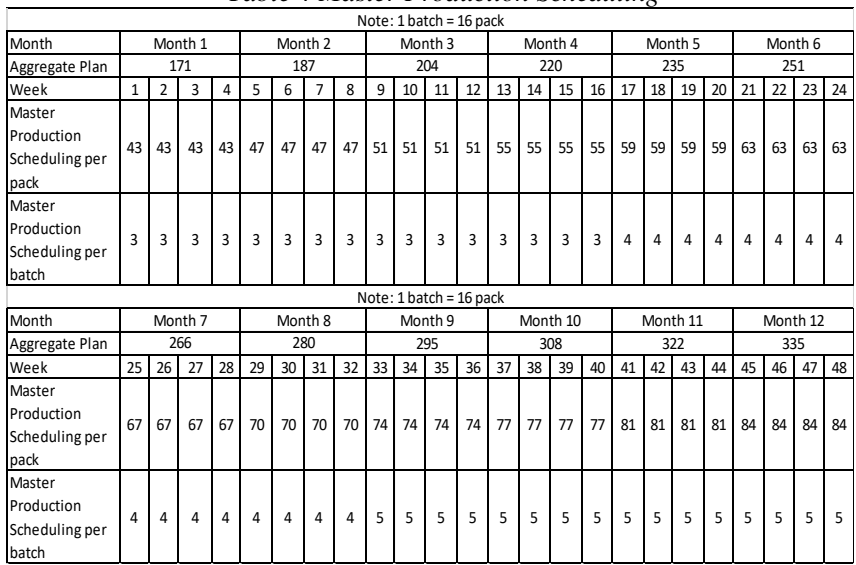




\section{$\therefore$ ATLANTIS PRESS}

We adjust the demand from per packs into per batch for the production process, because the dough had a dose to produce one batch of the product as much as 16 packs. In addition, we also do the rounding up to master production scheduling in to per batch, because in reality, we must do the production per one batch, not in a decimal calculation.

\section{Lot Sizing}

Lot sizing techniques is one of the techniques used to determine how much the amount of material must be ordered, which will minimize the amount of components order and the total cost of inventory. The type of raw materials used in the production process is divided into two types, perishable and non-perishable material. So for perishable component, the lot sizing used was lot for lot (LFL), whereas for the nonperishable component, we make comparisons between lot for lot (LFL) method with economic order quantity (EOQ) method to get the most efficient of lot sizing.

\section{Lot For Lot (LFL)}

Lot for lot (LFL) which is a method to minimize the inventory in accordance with the idea of producing the required amount, that the amount of inventory kept to a minimum even generate the absence of inventory. The calculation of lot for lot (LFL) method for perishable component and non-perishable components are as follows.

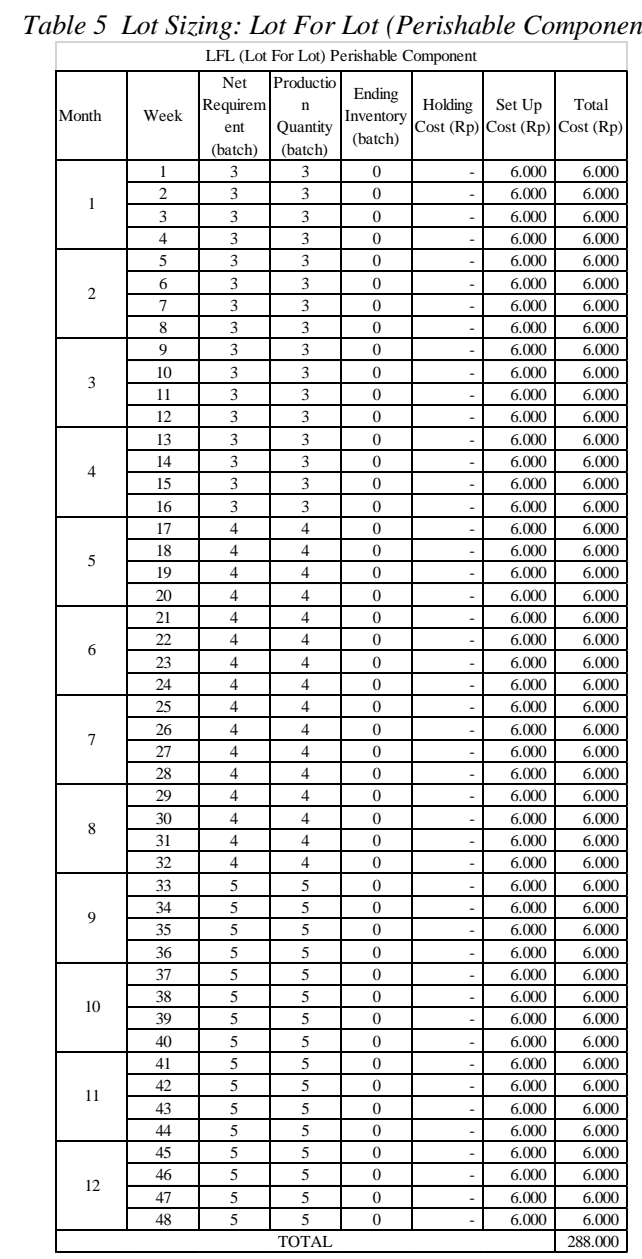

Table 6 Lot for Lot (Non-Perishable Components)

\begin{tabular}{|c|c|c|c|c|c|c|c|}
\hline \multicolumn{8}{|c|}{ Lot For Lot (LFL) Non-Perishable Components } \\
\hline Month & Week & $\begin{array}{c}\text { Net } \\
\text { Requireme } \\
\text { nt (batch) }\end{array}$ & $\begin{array}{c}\text { Production } \\
\text { Quantity } \\
\text { (batch) }\end{array}$ & \begin{tabular}{|c|} 
Ending \\
Inventory \\
(batch)
\end{tabular} & $\begin{array}{c}\text { Holding } \\
\text { Cost (Rp) }\end{array}$ & $\begin{array}{c}\text { Set Up } \\
\text { Cost (Rp) }\end{array}$ & \begin{tabular}{|c} 
Total Cost \\
(Rp)
\end{tabular} \\
\hline \multirow{4}{*}{1} & 1 & 3 & 3 & 0 & - & 32.000 & 32.000 \\
\hline & 2 & 3 & 3 & 0 & - & 32.000 & 32.000 \\
\hline & 3 & 3 & 3 & 0 & - & 32.000 & 32.000 \\
\hline & 4 & 3 & 3 & 0 & - & 32.000 & 32.000 \\
\hline \multirow{4}{*}{2} & 5 & 3 & 3 & 0 & - & 32.000 & 32.000 \\
\hline & 6 & 3 & 3 & 0 & - & 32.000 & 32.000 \\
\hline & 7 & 3 & 3 & 0 & - & 32.000 & 32.000 \\
\hline & 8 & 3 & 3 & 0 & - & 32.000 & 32.000 \\
\hline \multirow{4}{*}{3} & 9 & 3 & 3 & 0 & - & 32.000 & 32.000 \\
\hline & 10 & 3 & 3 & 0 & - & 32.000 & 32.000 \\
\hline & 11 & 3 & 3 & 0 & - & 32.000 & 32.000 \\
\hline & 12 & 3 & 3 & 0 & - & 32.000 & 32.000 \\
\hline \multirow{4}{*}{4} & 13 & 3 & 3 & 0 & - & 32.000 & 32.000 \\
\hline & 14 & 3 & 3 & 0 & - & 32.000 & 32.000 \\
\hline & 15 & 3 & 3 & 0 & - & 32.000 & 32.000 \\
\hline & 16 & 3 & 3 & 0 & - & 32.000 & 32.000 \\
\hline \multirow{4}{*}{5} & 17 & 4 & 4 & 0 & - & 32.000 & 32.000 \\
\hline & 18 & 4 & 4 & 0 & - & 32.000 & 32.000 \\
\hline & 19 & 4 & 4 & 0 & - & 32.000 & 32.000 \\
\hline & 20 & 4 & 4 & 0 & - & 32.000 & 32.000 \\
\hline \multirow{4}{*}{6} & 21 & 4 & 4 & 0 & - & 32.000 & 32.000 \\
\hline & 22 & 4 & 4 & 0 & - & 32.000 & 32.000 \\
\hline & 23 & 4 & 4 & 0 & - & 32.000 & 32.000 \\
\hline & 24 & 4 & 4 & 0 & - & 32.000 & 32.000 \\
\hline \multirow{4}{*}{7} & 25 & 4 & 4 & 0 & - & 32.000 & 32.000 \\
\hline & 26 & 4 & 4 & 0 & - & 32.000 & 32.000 \\
\hline & 27 & 4 & 4 & 0 & - & 32.000 & 32.000 \\
\hline & 28 & 4 & 4 & 0 & - & 32.000 & 32.000 \\
\hline \multirow{4}{*}{8} & 29 & 4 & 4 & 0 & - & 32.000 & 32.000 \\
\hline & 30 & 4 & 4 & 0 & - & 32.000 & 32.000 \\
\hline & 31 & 4 & 4 & 0 & - & 32.000 & 32.000 \\
\hline & 32 & 4 & 4 & 0 & - & 32.000 & 32.000 \\
\hline \multirow{4}{*}{9} & 33 & 5 & 5 & 0 & - & 32.000 & 32.000 \\
\hline & 34 & 5 & 5 & 0 & - & 32.000 & 32.000 \\
\hline & 35 & 5 & 5 & 0 & - & 32.000 & 32.000 \\
\hline & 36 & 5 & 5 & 0 & - & 32.000 & 32.000 \\
\hline \multirow{4}{*}{10} & 37 & 5 & 5 & 0 & - & 32.000 & 32.000 \\
\hline & 38 & 5 & 5 & 0 & - & 32.000 & 32.000 \\
\hline & 39 & 5 & 5 & 0 & - & 32.000 & 32.000 \\
\hline & 40 & 5 & 5 & 0 & - & 32.000 & 32.000 \\
\hline \multirow{4}{*}{11} & 41 & 5 & 5 & 0 & - & 32.000 & 32.000 \\
\hline & 42 & 5 & 5 & 0 & - & 32.000 & 32.000 \\
\hline & 43 & 5 & 5 & 0 & - & 32.000 & 32.000 \\
\hline & 44 & 5 & 5 & 0 & - & 32.000 & 32.000 \\
\hline \multirow{4}{*}{12} & 45 & 5 & 5 & 0 & - & 32.000 & 32.000 \\
\hline & 46 & 5 & 5 & 0 & - & 32.000 & 32.000 \\
\hline & 47 & 5 & 5 & 0 & - & 32.000 & 32.000 \\
\hline & 48 & 5 & 5 & 0 & - & 32.000 & 32.000 \\
\hline \multicolumn{7}{|c|}{ TOTAL } & 1.536 .000 \\
\hline
\end{tabular}

From these results, it was found that by using the LFL method, the company would have zero rupiah holding cost for the purchase made in accordance with the needs. Meanwhile, the company will have more expensive set up cost. Thus, the total cost will be spent by the company when using this method is Rp1.536.000 for non-perishable component and Rp288.000 for perishable component.

\section{Economic Order Quantity (EOQ)}

EOQ (Economic Order Quantity) is the method which be employed to minimize the total inventory cost by finding the point of balance between the holding cost and set up cost. First, we seek a formula of EOQ method as follows below.

$$
Q^{*}=\sqrt{\frac{2 D S}{H}}
$$

Note:

$\mathrm{D}=$ Demand

$\mathrm{S}=$ Set up cost

$\mathrm{H}=$ Holding cost 
KISSE company's demand during the year is 192 batch, the set up cost is Rp32.000 per order, and the holding cost per 48 weeks is Rp530.719. Therefore, the formula obtained from EOQ models from KISSE company as follows.

$$
\begin{gathered}
\mathrm{Q}=\frac{\sqrt{2 \times 192 \times 32000}}{\sqrt{530719}} \\
\mathrm{Q}=\frac{\sqrt{12288000}}{\sqrt{530719}} \\
\mathrm{Q}=\sqrt{23,15} \\
\mathrm{Q}=4,8 \text { batch } \\
\mathrm{Q} \approx 5 \text { batch }
\end{gathered}
$$

\begin{tabular}{|c|c|c|c|c|c|c|c|}
\hline Month & Week & \begin{tabular}{|c|} 
Net \\
Requirem \\
ent \\
(batch)
\end{tabular} & \begin{tabular}{|c|} 
Productio \\
$\mathrm{n}$ \\
Quantity \\
(batch)
\end{tabular} & $\begin{array}{l}\text { Ending } \\
\text { Inventory } \\
\text { (batch) }\end{array}$ & $\begin{array}{c}\text { Holding } \\
\text { Cost (Rp) }\end{array}$ & $\begin{array}{c}\text { Set Up } \\
\text { Cost (Rp) }\end{array}$ & $\begin{array}{c}\text { Total } \\
\text { Cost (Rp) }\end{array}$ \\
\hline \multirow{4}{*}{1} & 1 & 3 & 3 & 0 & - & 6.000 & 6.000 \\
\hline & 2 & 3 & 3 & 0 & - & 6.000 & 6.000 \\
\hline & 3 & 3 & 3 & 0 & - & 6.000 & 6.000 \\
\hline & 4 & 3 & 3 & 0 & - & 6.000 & 6.000 \\
\hline \multirow{4}{*}{2} & 5 & 3 & 3 & 0 & - & 6.000 & 6.000 \\
\hline & 6 & 3 & 3 & 0 & - & 6.000 & 6.000 \\
\hline & 7 & 3 & 3 & 0 & - & 6.000 & 6.000 \\
\hline & 8 & 3 & 3 & 0 & - & 6.000 & 6.000 \\
\hline \multirow{4}{*}{3} & 9 & 3 & 3 & 0 & - & 6.000 & 6.000 \\
\hline & 10 & 3 & 3 & 0 & - & 6.000 & 6.000 \\
\hline & 11 & 3 & 3 & 0 & - & 6.000 & 6.000 \\
\hline & 12 & 3 & 3 & 0 & - & 6.000 & 6.000 \\
\hline \multirow{4}{*}{4} & 13 & 3 & 3 & 0 & - & 6.000 & 6.000 \\
\hline & 14 & 3 & 3 & 0 & - & 6.000 & 6.000 \\
\hline & 15 & 3 & 3 & 0 & - & 6.000 & 6.000 \\
\hline & 16 & 3 & 3 & 0 & - & 6.000 & 6.000 \\
\hline \multirow{4}{*}{5} & 17 & 4 & 4 & 0 & - & 6.000 & 6.000 \\
\hline & 18 & 4 & 4 & 0 & - & 6.000 & 6.000 \\
\hline & 19 & 4 & 4 & 0 & - & 6.000 & 6.000 \\
\hline & 20 & 4 & 4 & 0 & - & 6.000 & 6.000 \\
\hline \multirow{4}{*}{6} & 21 & 4 & 4 & 0 & & 6.000 & 6.000 \\
\hline & 22 & 4 & 4 & 0 & - & 6.000 & 6.000 \\
\hline & 23 & 4 & 4 & 0 & - & 6.000 & 6.000 \\
\hline & 24 & 4 & 4 & 0 & - & 6.000 & 6.000 \\
\hline \multirow{4}{*}{7} & 25 & 4 & 4 & 0 & - & 6.000 & 6.000 \\
\hline & 26 & 4 & 4 & 0 & - & 6.000 & 6.000 \\
\hline & 27 & 4 & 4 & 0 & 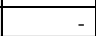 & 6.000 & 6.000 \\
\hline & 28 & 4 & 4 & 0 & - & 6.000 & 6.000 \\
\hline \multirow{4}{*}{8} & 29 & 4 & 4 & 0 & & 6.000 & 6.000 \\
\hline & 30 & 4 & 4 & 0 & - & 6.000 & 6.000 \\
\hline & 31 & 4 & 4 & 0 & 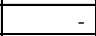 & 6.000 & 6.000 \\
\hline & 32 & 4 & 4 & 0 & - & 6.000 & 6.000 \\
\hline \multirow{4}{*}{9} & 33 & 5 & 5 & 0 & 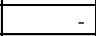 & 6.000 & 6.000 \\
\hline & 34 & 5 & 5 & 0 & - & 6.000 & 6.000 \\
\hline & 35 & 5 & 5 & 0 & 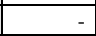 & 6.000 & 6.000 \\
\hline & 36 & 5 & 5 & 0 & 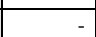 & 6.000 & 6.000 \\
\hline \multirow{4}{*}{10} & 37 & 5 & 5 & 0 & - & 6.000 & 6.000 \\
\hline & 38 & 5 & 5 & 0 & 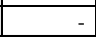 & 6.000 & 6.000 \\
\hline & 39 & 5 & 5 & 0 & 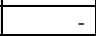 & 6.000 & 6.000 \\
\hline & 40 & 5 & 5 & 0 & - & 6.000 & 6.000 \\
\hline \multirow{4}{*}{11} & 41 & 5 & 5 & 0 & - & 6.000 & 6.000 \\
\hline & 42 & 5 & 5 & 0 & & 6.000 & 6.000 \\
\hline & 43 & 5 & 5 & 0 & - & 6.000 & 6.000 \\
\hline & 44 & 5 & 5 & 0 & & 6.000 & 6.000 \\
\hline \multirow{4}{*}{12} & 45 & 5 & 5 & 0 & & 6.000 & 6.000 \\
\hline & 46 & 5 & 5 & 0 & & 6.000 & 6.000 \\
\hline & 47 & 5 & 5 & 0 & & 6.000 & 6.000 \\
\hline & 48 & 5 & 5 & 0 & - & 6.000 & 6.000 \\
\hline & & & TA & & & & 288.000 \\
\hline
\end{tabular}

\begin{tabular}{|c|c|c|c|c|c|c|c|}
\hline \multicolumn{8}{|c|}{ Economic Order Quantity (EOQ) Non-Perishable Components } \\
\hline Month & Week & $\begin{array}{c}\text { Net } \\
\text { Requirement } \\
\text { (batch) }\end{array}$ & $\begin{array}{l}\text { Production } \\
\text { Quantity } \\
\text { (batch) }\end{array}$ & \begin{tabular}{|l} 
Ending \\
Inventory \\
(batch)
\end{tabular} & \begin{tabular}{|c} 
Holding \\
Cost $(\mathrm{Rp})$
\end{tabular} & \begin{tabular}{|c} 
Set Up \\
Cost (Rp)
\end{tabular} & $\begin{array}{l}\text { Total Cost } \\
(\mathrm{Rp})\end{array}$ \\
\hline \multirow{4}{*}{1} & 1 & 3 & 5 & 2 & 25.742 & 32.000 & 57.742 \\
\hline & 2 & 3 & 5 & 5 & 51.484 & 32.000 & 83.484 \\
\hline & 3 & 3 & 0 & 2 & 21.941 & & 21.941 \\
\hline & 4 & 3 & 5 & 4 & 47.683 & 32.000 & 79.68 .3 \\
\hline \multirow{4}{*}{2} & 5 & 3 & 0 & 1 & 15.376 & & 15.376 \\
\hline & 6 & 3 & 5 & 3 & 38.354 & 32.000 & 70.354 \\
\hline & 7 & 3 & 0 & 1 & 6.047 & & 6.047 \\
\hline & 8 & 3 & 5 & 3 & 29.025 & 32.000 & 61.025 \\
\hline \multirow{4}{*}{3} & $\begin{array}{ll}9 \\
\end{array}$ & 3 & 5 & 4 & 49.065 & 32.000 & 81.065 \\
\hline & 10 & 3 & 0 & 1 & 13.821 & & 13.821 \\
\hline & 11 & 3 & 5 & 3 & 33.862 & 32.000 & 65.862 \\
\hline & 12 & 3 & 5 & 5 & 53.903 & 32.000 & 85.903 \\
\hline \multirow{4}{*}{4} & 13 & 3 & 0 & 1 & 15.894 & & 15.894 \\
\hline & 14 & 3 & 5 & 3 & 33.171 & 32.000 & 65.171 \\
\hline & 15 & 3 & 5 & 5 & 50.448 & 32.000 & 82.448 \\
\hline & 16 & 3 & 0 & 1 & 12.439 & & 12.439 \\
\hline \multirow{4}{*}{5} & 17 & 4 & 5 & 2 & 27.124 & 32.000 & 59.124 \\
\hline & 18 & 4 & 5 & 4 & 41.809 & 32.000 & 73.809 \\
\hline & 19 & 4 & 0 & 0 & 1.209 & & 1.209 \\
\hline & 20 & 4 & 5 & 1 & 15.894 & 32.000 & 47.894 \\
\hline \multirow{4}{*}{6} & 21 & 4 & 5 & 3 & 27.815 & 32.000 & 59.815 \\
\hline & 22 & 4 & 5 & 4 & 39.736 & 32.000 & 71.736 \\
\hline & 23 & 4 & 5 & 5 & 51.657 & 32.000 & 83.657 \\
\hline & 24 & 4 & 0 & 1 & 8.293 & & 8.293 \\
\hline \multirow{4}{*}{7} & 25 & 4 & 5 & 2 & $\begin{array}{l}17.622 \\
\end{array}$ & 32.000 & 49.622 \\
\hline & 26 & 4 & 5 & 2 & 26.951 & 32.000 & 58.951 \\
\hline & 27 & 4 & 5 & 3 & 36.281 & 32.000 & 68.281 \\
\hline & 28 & 4 & 5 & 4 & 45.610 & 32.000 & 77.610 \\
\hline \multirow{4}{*}{8} & 29 & 4 & 5 & 5 & 52.521 & & 52.521 \\
\hline & 30 & 4 & 0 & 0 & 4.146 & & 4.146 \\
\hline & 31 & 4 & 5 & 1 & 11.057 & 32.000 & 43.057 \\
\hline & 32 & 4 & 5 & 2 & 17.968 & 32.000 & 49.968 \\
\hline \multirow{4}{*}{9} & 33 & 5 & 5 & 2 & 222.287 & 32.000 & 54.287 \\
\hline & 34 & 5 & 5 & 2 & 26.606 & 32.000 & 58.606 \\
\hline & 35 & 5 & 5 & 3 & 30.925 & 32.000 & 62.925 \\
\hline & 36 & 5 & 5 & 3 & 35.244 & 32.000 & 67.244 \\
\hline \multirow{4}{*}{10} & 37 & 5 & 5 & 3 & 37.317 & 32.000 & 69.317 \\
\hline & 38 & 5 & 5 & 4 & 39.391 & 32.000 & 71.391 \\
\hline & 39 & 5 & 5 & 4 & 41.464 & 32.000 & 73.464 \\
\hline & 40 & 5 & 5 & 4 & 43.537 & 32.000 & 75.537 \\
\hline \multirow{4}{*}{11} & 41 & 5 & 5 & 4 & 43.191 & 32.000 & 75.191 \\
\hline & 42 & 5 & 5 & 4 & 42.846 & 32.000 & 74.846 \\
\hline & 43 & 5 & 5 & 4 & 42.500 & 32.000 & 74.500 \\
\hline & 44 & 5 & 5 & 4 & 42.155 & 32.000 & 74.155 \\
\hline \multirow{4}{*}{12} & 45 & 5 & 5 & 4 & 39.563 & 32.000 & 71.563 \\
\hline & 46 & 5 & 5 & 3 & 36.972 & 32.000 & 68.972 \\
\hline & 47 & 5 & 5 & 3 & 34.380 & 32.000 & 66.380 \\
\hline & 48 & 5 & 5 & 3 & 31.789 & 32.000 & 63.789 \\
\hline & & & & & & & 2.730 .118 \\
\hline
\end{tabular}

Table 7 LFL Perishable Component

LFL (Lot For Lot) Perishable Component
Table 8 Lot Sizing: Economic Order Quantity (Non-Perishable Component)

From these results, it can be seen that the holding cost's column at this calculation has different total holding cost, it is because net requirement per batch is rounding up, there after the ending inventory is also adapting it. And then, it was found with the EOQ method, the company will have an expensive holding cost, which increased their inventory cost. Meanwhile, the company will have quite efficient set up cost because the cost of transportation is only issued at the time the order is made. Thus, the total cost will be spent by the company when using this method is $\mathrm{Rp} 2.730 .118$ for non-perishable component.

The analysis result for the non-perishable component, for both of two methods, is explained as follow. It can be seen that the LFL method have total cost 1.536.000 rupiah, while EOQ Method have total cost 2.730.118 rupiah. It means EOQ method have total cost more expensive than using LFL method. However, because of the perishable component should use LFL method, then further analysis to determine more efficient results among them are using LFL (nonperishable components) - LFL (perishable component) and EOQ method (non-perishable components) - LFL (perishable component). 


\section{Afrumers PRESS}

If using the LFL - LFL, the costs to be incurred by the company amounted Rp1.536.000 + Rp288.000 $=1.824 .000$ rupiah. Meanwhile, if using EOQ - LFL, the costs to be incurred by the company amounted to Rp2.730.118 + Rp288.000 $=3.018 .118$ rupiah. Thus, we chose LFL method (nonperishable components) - LFL (perishable component) as lot sizing because it has a more efficient cost.

\section{Material Requirement Planning}

Material requirement planning is a method that used to control inventory and production planning especially to schedule and decide how much raw material is needed in producing goods. In MRP calculations, there are two parts, namely gross requirements planning and net requirements planning.

Gross Requirement Planning

Gross requirements planning is a calculation of the required date and the order release date of each component. After the existence of the above, it is time to make gross material requirements plan to know when the process is done and when to do order release. The gross material plan for the month 1 is as follows.

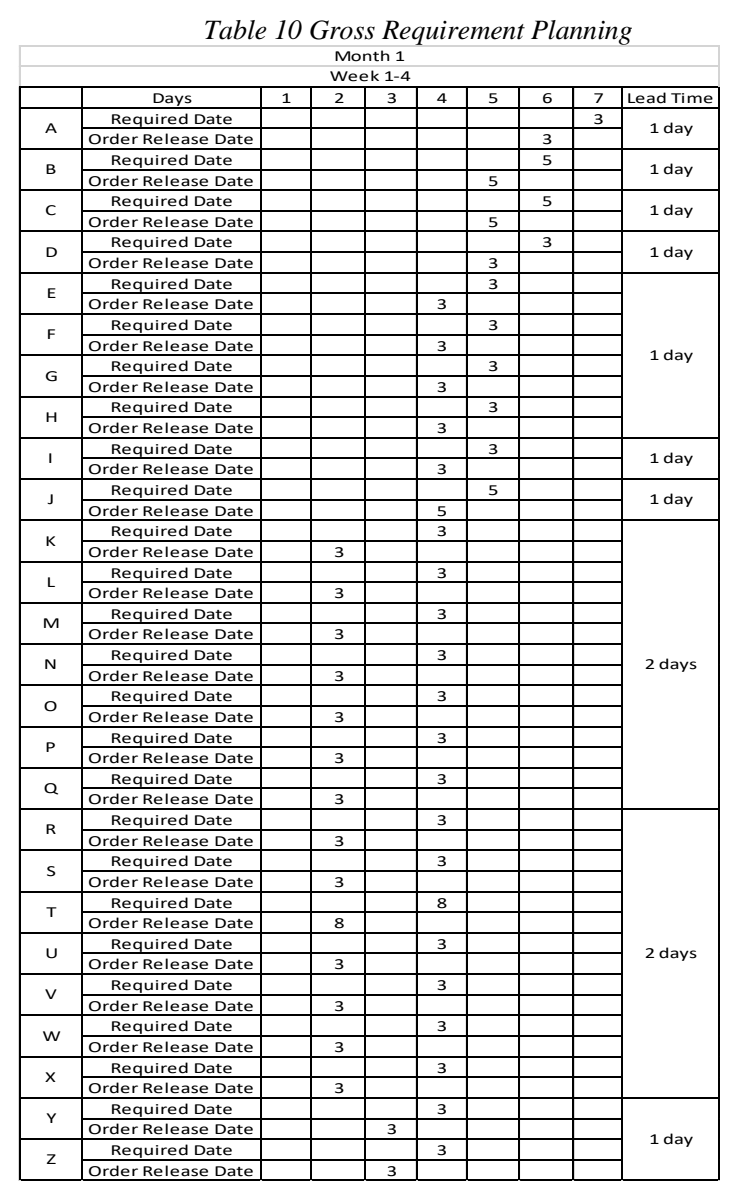

Net Requirement Planning

Net requirements planning is the overall calculation, ranging from gross requirement, scheduled receipts, on hand inventory, planned receipts, and the planned release. For inventory on hand, the company does not have inventory on hand at the beginning. This is because in a previous production activities, the company is only buying component for one production time. Then, for the planned receipts and planned releases, it is assumed that after the order for each component, the next morning the component is ready for use. This is because the purchases are made directly by the company, not to wait delivery by the supplier. After going through the gross requirement plan and determine the lot sizing method is most suitable. The next one is net requirement calculations concerning the plan. The result of net requirement plan are as follows.

Table 11.Net Requirement Planning

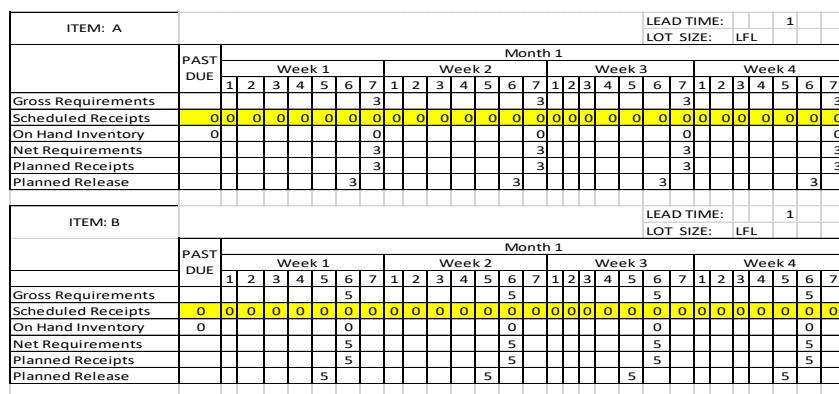

ITEM: C

\begin{tabular}{l|l}
\hline LOT SIZE: \\
\hline
\end{tabular} $\begin{array}{ll}\text { LEAD TIME: } & 1 \\ \text { LOT SIZE: LFL } & 1\end{array}$

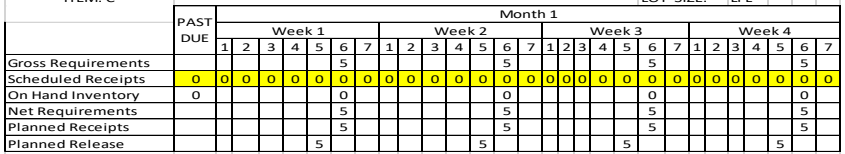

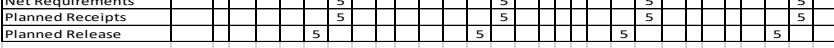

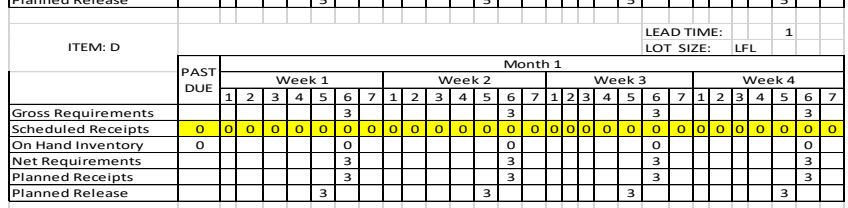

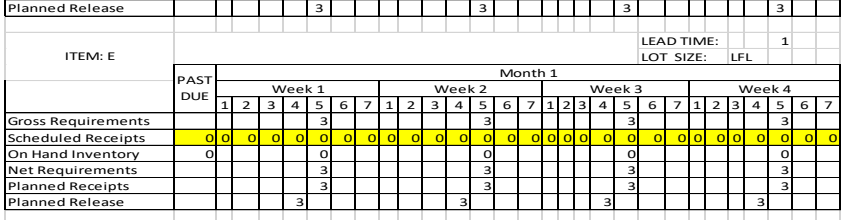

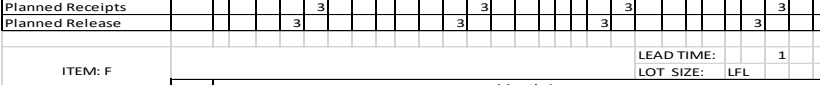

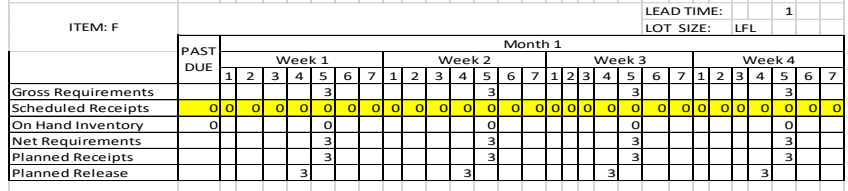

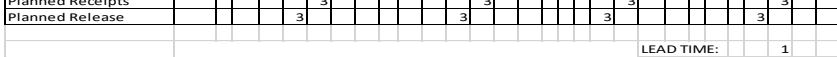

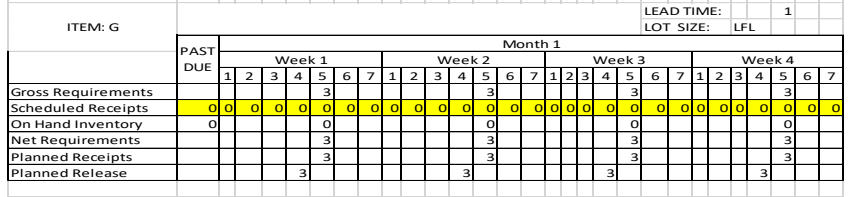

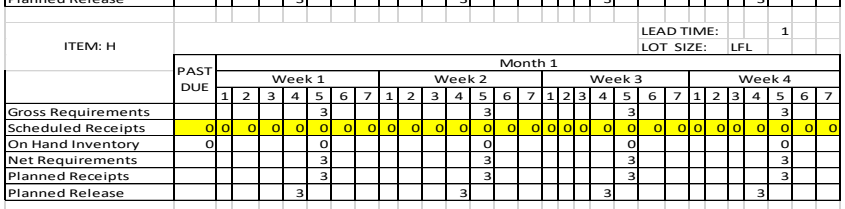

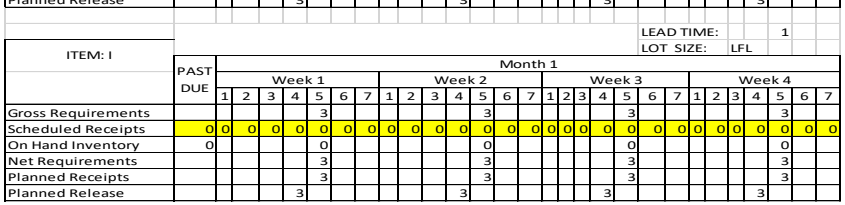




\section{AltanIs PRESS}

Table 11.Net Requirement Planning (Cont...)

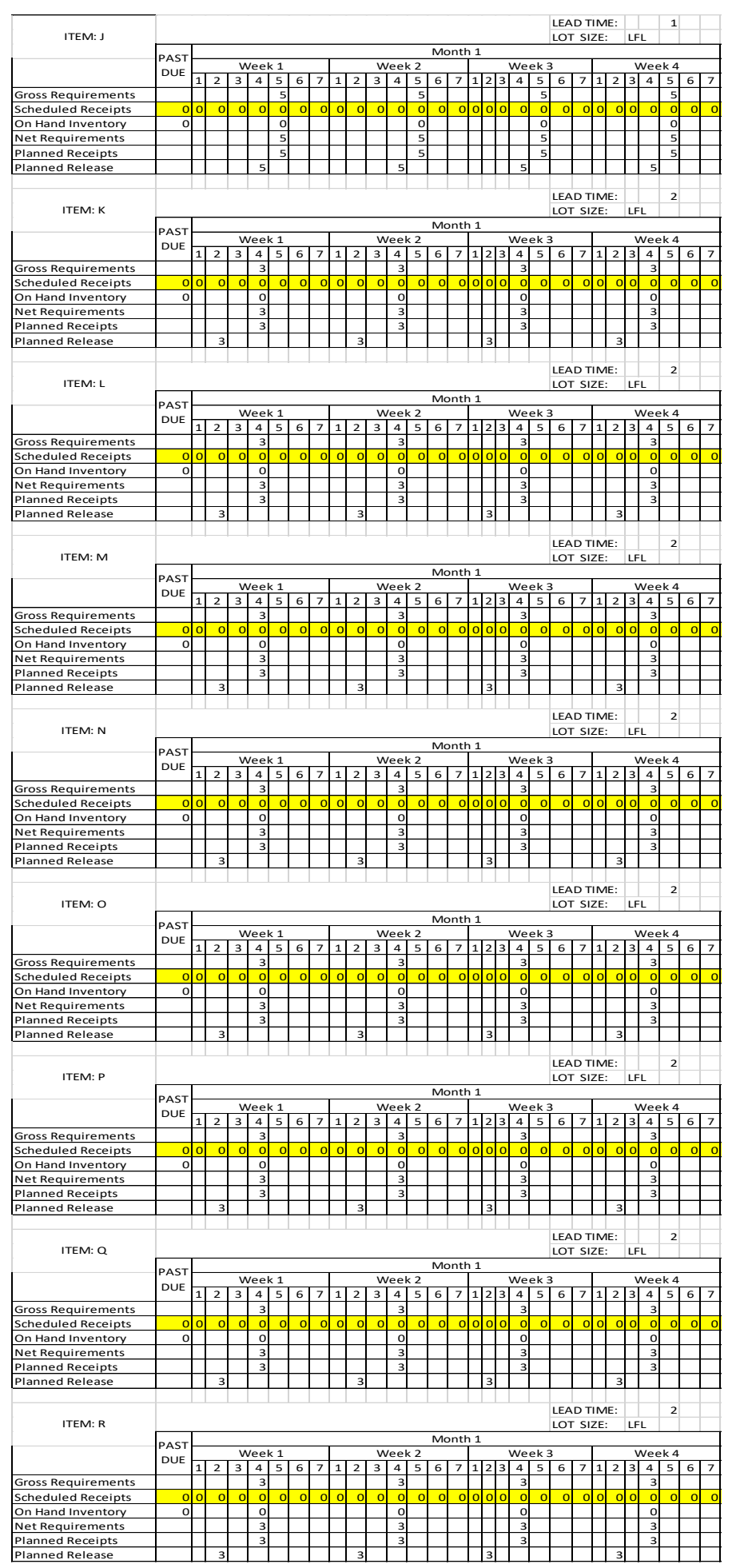

Table 11.Net Requirement Planning (Cont...)

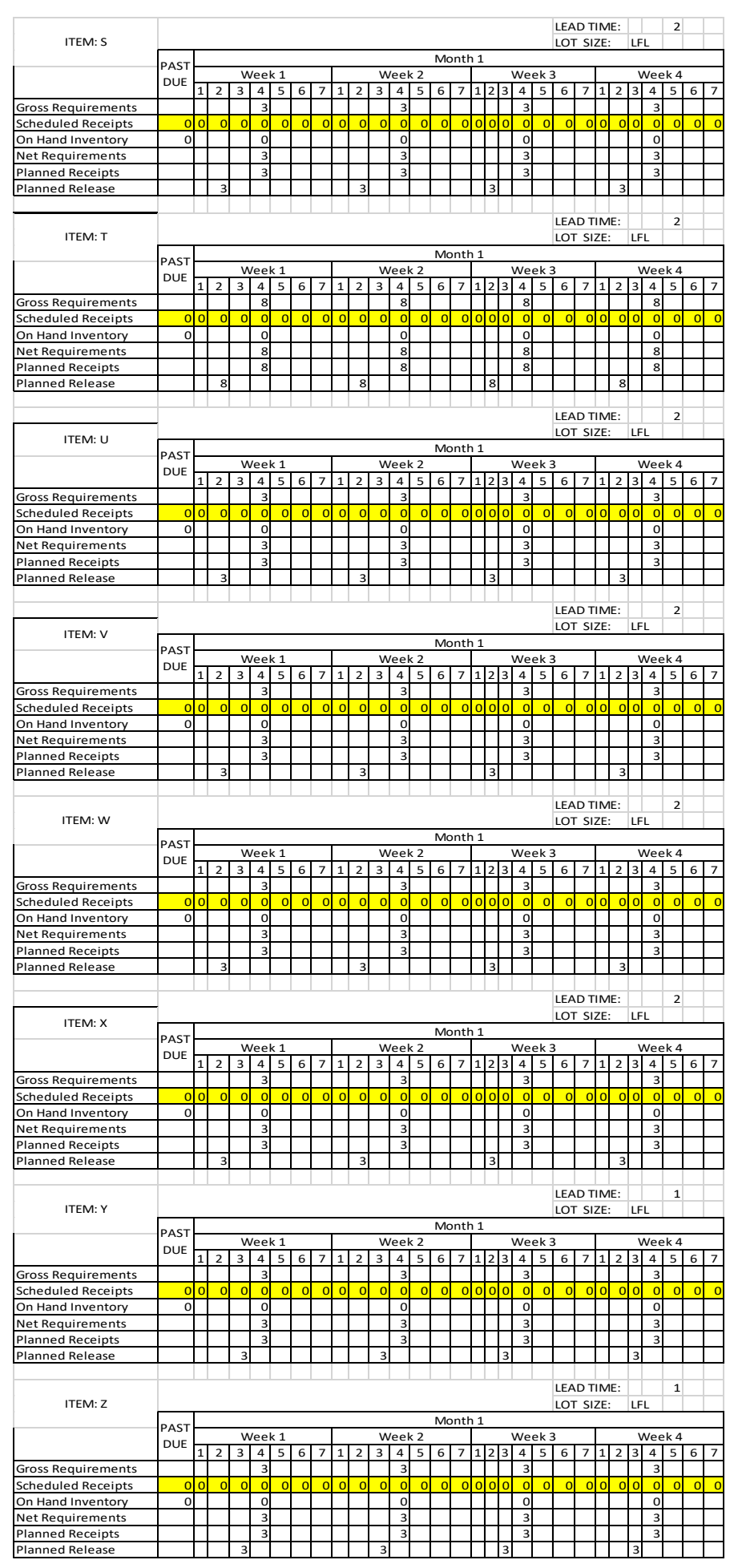




\section{CONCLUSION}

Based on data analysis above, it can be seen that the material requirement planning method has solved the problem in terms of inventory and production scheduling system for KISSE (Cookies Sehat) company. From the analysis' result, we have created a product structure along with the time phase product, so the company can manage with more accurate information on the production schedule. In addition, to streamline the time, then the production activity can be divided to the pre-production and production.

KISSE (Cookies Sehat) company can use lot sizing methods that is LFL method (non-perishable components) LFL (perishable component) to obtain a lower total cost of $165 \%$ compared with EOQ (non-perishable components) LFL (perishable component), so the company does not only minimize inventory but also save the costs. It is because, if using the LFL - LFL, the costs to be incurred by the company is $\operatorname{Rp} 1.536 .000+\operatorname{Rp} 288.000=\operatorname{Rp} 1.824 .000$. Meanwhile, if using EOQ - LFL, the costs to be incurred by the company amounted to $\mathrm{Rp} 2.730 .118+\mathrm{Rp} 288.000=\mathrm{Rp} 3.018 .118$.

Material requirements planning (MRP) makes the inventory system of raw materials more structured. Since the inventory had been scheduled properly, then the companies will be able to meet the market demand on time. With inventory system and production scheduling, companies are able to estimate the amount of raw materials needed, avoiding the scarcity of raw materials because they can be booked in advance, which can be set when the raw materials must be available, and able to determine the number and variants are produced each day in meeting overall demand.

\section{REFERENCES}

[1] Badan Pusat Statistik. (2016, March 14). Jumlah Perusahaan Industri Mikro dan Kecil Menurut 2-digit KBLI. Retrieved March 14, 2016, from https://www.bps.go.id/linkTableDinamis/view/id/1011

[2] Heizer, Jay., \& Render, Barry. (2014). Operation Management: Sustainability and Supply Chain Management (11th ed., ch. 12 \& 14). England: PEARSON.

[3] Graham, Paul. (2004). How to Make Wealth. Retrieved from http://www.paulgraham.com/wealth.html

[4] Startup Commons. (2016). Start up development phases. Retrieved May 11, 2016, from http://www.startupcommons.org/startup-developmentphases.html

[5] Greasley, Andrew. (1999). Operation Management in Business. London: Stanley Thornes.

[6] Jacobs, F. Robert., \& Chase, Richard B. (2014). Operation and Supply Chain Management (14th ed., ch 18 and 21). United States: Mc Graw-Hill.

[7] Kumar, S. Ani., \& Suresh, N. (2009). Operation Management (ch. 5, p. 105-106). New Delhi: New Age International.

[8] Stevensos, William J. (2002). Operation Management 7th Edition. New York: Mc Graw-Hill.

[9] Supardi, M.d. (2006). Metodologi Penelitian. Mataram: Yayasan Cerdas Press.

[10] Margono. (2005). Metode Penelitian Pendidikan. Jakarta: Rineka Cipta. 